\title{
Slovaks on Display. Otherness of the 'Eastern Brothers' at the Czechoslavic Ethnographic Exhibition in Prague 1895
}

\author{
Milan Ducháček \\ Centre for the History of Sciences and Humanities - Institute of Contemporary History \\ of the Czech Academy of Sciences, Prague \\ Department of History, Faculty of Science, Humanities and Education, \\ Technical University of Liberec, Czech Republic
}

\begin{abstract}
This paper is devoted to how the Slovaks were staged, encountered and recognized by the Czechs at the Czechoslavic Ethnographic Exhibition organized in Prague in 1895. The Slovaks, living during the last period of the Hungarian Kingdom, were perceived by the Czechs as an ostensibly familiar collective of 'Slavic relatives.' The less the Czech urban society in the last decades of the $19^{\text {th }}$ century kept its ties with the slowly, but inevitably modernized countryside, the more the picture of the 'Czechoslavic' imagined community required a different area for placing its 'native cottages' into. In reconceptualizing the modern Czech 'geography of knowledge', even the most notable Czech specialists in Slavic studies have adopted the notion that Slovaks were in fact an 'eastern branch' of the 'Czechoslavic people settled in Bohemia, Moravia, Silesia as well as the Northwest of Hungary'. Consequently, the idea of an ethnocentric, 'national' exhibition needed a demonstrative extension of the 'Czech territory' on to the East. To achieve a public demonstration of the idea, the later renowned architect Dušan Jurkovič invited a small group of people from the Trenčín and Zvolen/Detva regions to act as 'Slovaks' at the exhibition and so they did, wearing 'typical' folk costumes, singing and dancing in a peculiar style. They were viewed as a strangely exotic 'Slovak colony' by visitors and Czech journalists alike. The public response to the show only reinforced the petrification of the Czech collective stereotype of the 'Slovak people' as an underdeveloped poor community, 'unspoiled' by 'western' civilization, yet still resisting Hungarization. This ingrained discourse of 'otherness' survived among most of the Czechs until the establishment of the Czechoslovak republic in 1918, resulting in a growing wave of mutual misunderstandings.
\end{abstract}

Keywords: Czechoslavic Ethnographical Exhibition 1895, Slovak ethnology, Otherness, Czechoslovakism, Dušan Jurkovič, Geography of Knowledge, Groupness 


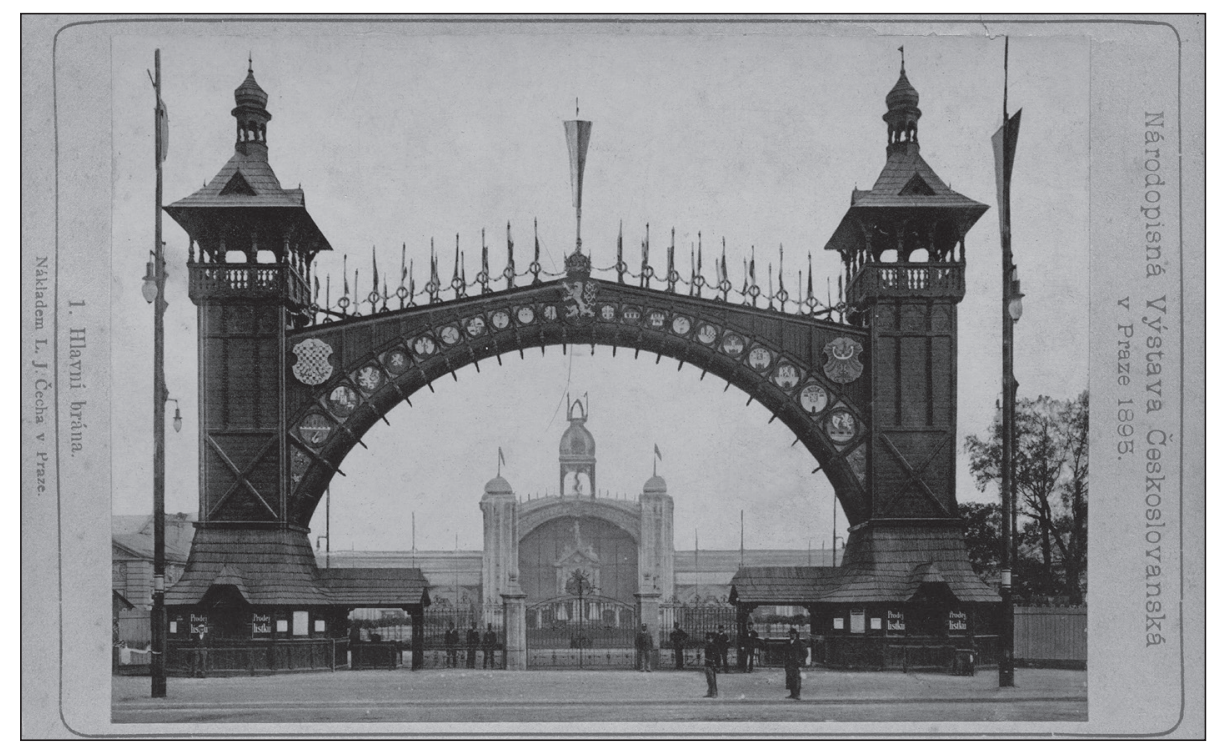

Figure 1. The Entrance to the exhibition area in Prague-Holešovice with the Industrial Palace, the heart of the 1891 Jubilee Exhibition, in the background. The area was already accessible by tram, which was constructed by the Czech engineer František Křižík. Cabinet card published by J. L. Čech, collotype, 1895, Scheufler Collection

Within the discussion on otherness the hereby presented case can be viewed as quite an ordinary one. It concerns the stereotyping of Slovaks by the Czechs at the end of the $19^{\text {th }}$ century. In specific, this analysis reflects on the Czechoslavic Ethnographical Exhibition held in Prague in 1895, from May 15 until October 26 (FILIPOVÁ 2011, NVČ 1897:45, 507-518). (Fig. 1). This particular event was very influential in terms of the re-conceptualization of the image of a national self-determination of the Czechs as the recorded number of visitors reached two million (NVČ 1897:518, 533). Not all visitors were Czech. Moreover, many individuals visited the exhibition more than once. However, almost a third of the approximate 5.75 million people in the Bohemian lands who considered Czech to be their mother tongue during the 1890s still represented a remarkable percentage of the visitors. ${ }^{1}$

The whole exhibition area, which was located in Holešovice in the Vltava riverside district at the northeastern border of late $19^{\text {th }}$-century Prague, followed the location of its 1891 predecessor, using its central buildings for the interior exhibits (see Fig. 1). ${ }^{2}$ The outdoor divisions of the exhibition offered a broad number of historical or

1 Out of almost 9 million inhabitants living in the Czech lands around 1895, approx. 35\% were officially accounted for as Germans.

2 The Prague - Holešovice exhibition area (still referred to as Výstaviště, meaning Exhibiton Area, in the contemporary 7th district of Prague) has been used for the same or similar purposes during the entire $20^{\text {th }}$ century, offering opportunities for mass political meetings (including the Communist era), exhibitions and different kinds of festivals and fairs. Some of the buildings from the late $19^{\text {th }}$ century are still in use. 
ethnographical objects. It consisted of a replica of a $16^{\text {th }}$ century Renaissance Prague street and other notable pavilions, linked with the revival of the 'historical roots' of the collective self-imagination of Czech Urban society formed by the ideas of romantic historicism (THIESSE 2007:161-195).

In the following account, I try to draw attention to the rural part of the exhibition in specific. The so called 'Exhibition Village' allegedly became the most visited and recalled part of the whole event by the end of the exhibition (for a more detailed picture see FILIPOVÁ 2011:22-27; NVČ 1897:97). I perceive the 'village' as a kind of spectacle; a stage where the 'bourgeois' in particular, but also in great part, the small town as well as the rural audience were offered an opportunity to transgress the selfconcept of Czech society somewhere outside (although not necessarily back) into an imaginary space of collective origin, usually connected with an image of the 'people' (JERVIS 1999:24-27, 38-39). ${ }^{3}$

There is often more alterity and otherness to be found in the surrounding neighborhood and in things we are used to than usually meet the eye. This was also the case in terms of the communities in the late Austro-Hungarian Monarchy after the implementation of dualism and the division of the empire into two different parts, especially as it concerned the politics of nationality (HASLINGER 2010:4-40,91n; MAXWELL 2009). In this particular case, we come to staging, encountering and recognizing the Slovak 'relatives' (HASLINGER 2010:100-106) in a context of previously fixed visual stereotypes only to end up with fabricating the fictional and very influential recognition, Wiedererkennen in Fabian's terms (FABIAN 2001:161-162), of Slovak alterity; rediscovering the 'otherness' of the ostensibly familiar collective, thus changing the concept of groupness as a category of social practice bound to the image of a 'Czechoslavic' collective identity.

The framework outlined above could be interpreted in opposition with the process of encountering and becoming 'familiar' with the 'exotic other' (JoBS - MACKENTHUN 2011:7-11; FABIAN 2006). Therefore, this paper can be read as an attempt to illuminate one of the ways of transgressing the modernity of 'uncanny' urban Czech society (WoLFREYs 2008:172) through staging the 'domestic Otherness' available within the boundaries of the Central-European imagination of 'Noncolonial Orientalism.' Unlike the reflection of the 'Orient' or 'Exoticism' within the colonial Empires, my intent is to address the internal 'whiggish' reflection of the 'East' of the European multinational states as the less civilized and underdeveloped areas, a problem overlapping beyond the common bigotry typically shown by historical actors in encountering the ethnic 'exoticism' of anyone other than those of 'European’ origin (KonRÁD 2011:54-75; DEMSKI et al. 2013; LEMMEN 2013:210-212, 220).

\section{IN SEARCH OF THE UNITY OF THE 'CZECHOSLAVIC' PEOPLE}

It is common in the historiography of nationalism to understand the industrial and ethnographical exhibitions organized during the latter half of the $19^{\text {th }}$ century as symbolic representations of emerging national differences. At the same time, they can be reflected as

\footnotetext{
3 I would like to thank Pavel Scheufler, photographer and historian of photography, for allowing me to use a few pictures from his private family photo collection for this paper; enhancing and digitalising them from the original sources for this purpose.
} 


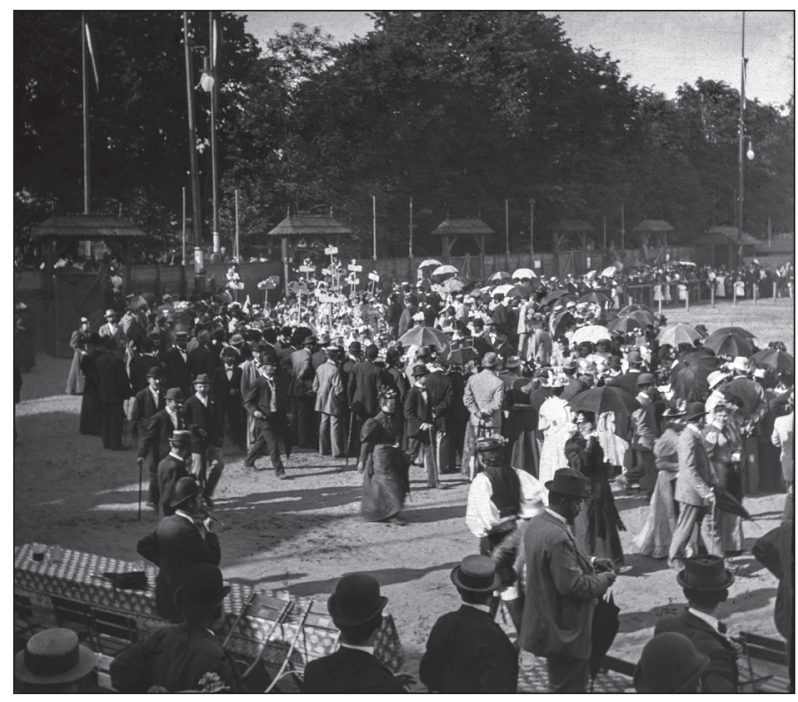

Figure 2. Most of the visitors of the Ethnographical Exhibition were Czech urban citizens. The wooden fence of the Exhibition village is visible in the background. Photo by F. Krátký, half of the colored stereodiapositive, 1895, Scheufler Collection a specific cultural practice, most especially as the mobilizing force and social self-determination of the modernized European urban societies (BRUBAKER 2015; Hroch 2015; THIESSE 2007; LeERSSEN 2006; PENNY 2002). They can also be viewed as stages for the recognition of otherness (ABBATTISTA 2015b). Unlike the industrial exhibitions that focused on the modernization, development and social progress bound with it, these ethnographic exhibitions functioned as a kind of time machine, preserving the ideas of neoromantic historicism or even the image of the primordial stages of mankind (ABBATTISTA 2015a; ABBATTISTA - IANNUZZI 2016). (Fig. 2)

Despite the non-existence of any specifically Czech concept of colonial policy, the Bohemian lands are no exception. The first Jubilee Industrial Exhibition, held in Prague in 1891, was significant with the demonstrative denial of the German speaking community to participate (FILIPOvá 2011:16; HLAVAČKA - KolÁř 1991; OKURKA 2009; 2016:150199). The same attitude and social division characterized its ethnographic follower, dedicated to the then utmost popular vision of a nation as an ethnographical individual, in this particular case a Czech or 'Czechoslavic' one (DuCHÁčEK 2014; KoDAJové 2009; cf. Lozoviuk 2008). Unlike the Jubilee Exhibition, this time, in 1895, the Hungarian Slovaks also took part in it; retrospectively rendering this spectacular event into the first broader public demonstration of the later asserted 'Czechoslovak national unity' (DUCHÁČEK 2014:195; BROUČEK 1984; 2015).

As it is widely known, even the foremost Czech specialists in Slavic studies, such as the linguist František Pastrnek, lived with the persuasion that the Slovaks occupying the so called 'Upper Hungary' were in fact an 'eastern branch of the Czechoslavic people', who settled in Bohemia, Moravia, Silesia and also in the Northwest of the former Hungarian Kingdom already in the early Middle Ages (NVČ 1897:76-77; BROUČEK 2015:51; HoLLÝ 2012; 2013). The sporadic, but proudly celebrated presence of the Slovaks from Hungary at the exhibition was perceived as a symbolic gesture, "a clear testimony that they are and want to be an integral part of the Czechoslavic nation, even though the border, state power and foreign national violence would have wanted them to be divided from us" (NVČ 1897:511). This idea of 'national' unity was also demonstrated symbolically on October the $19^{\text {th }}$, in the form of a 'living picture'; a collective static scene called "Homage of the Czechoslavic Tribes", assembled in front of the official visit of the Archduke Karl Ludwig accompanied by his wife Maria Theresia (NVČ 1897:513-514). 
Nevertheless, brothers or not, this did not mean that the Czechs counted the Hungarian Slovaks as equal (MAXwell 2009:141-165). On the contrary, they wanted and needed to keep the picture of Hungarian Slovaks as primordial as possible. Hungarian Slovaks were viewed as the "genuine, idiosyncratic people unspoiled by modern civilization", as it was emphasized in the huge retrospective volume dedicated to the Czechoslavic Ethnographic Exhibition (NVČ 1897:193).

The reason for this is apparent: the less the Czech educated middle-class in the cities kept its ties with the vanishing and inevitably modernized countryside the more the picture of a 'Czechoslavic' imagined community required another arena for putting their mythical 'native cottages' into; thus preserving the hilly regions of Slovakia as a kind of national cradle, recalling the tribal, primordial origins of the 'Czechoslavic nation' (MACURA 1997; for the Slovak reception see URBAN 1972).

\section{TWO KINDS OF SLOVAKS AND HOW TO RECOGNIZE THEM}

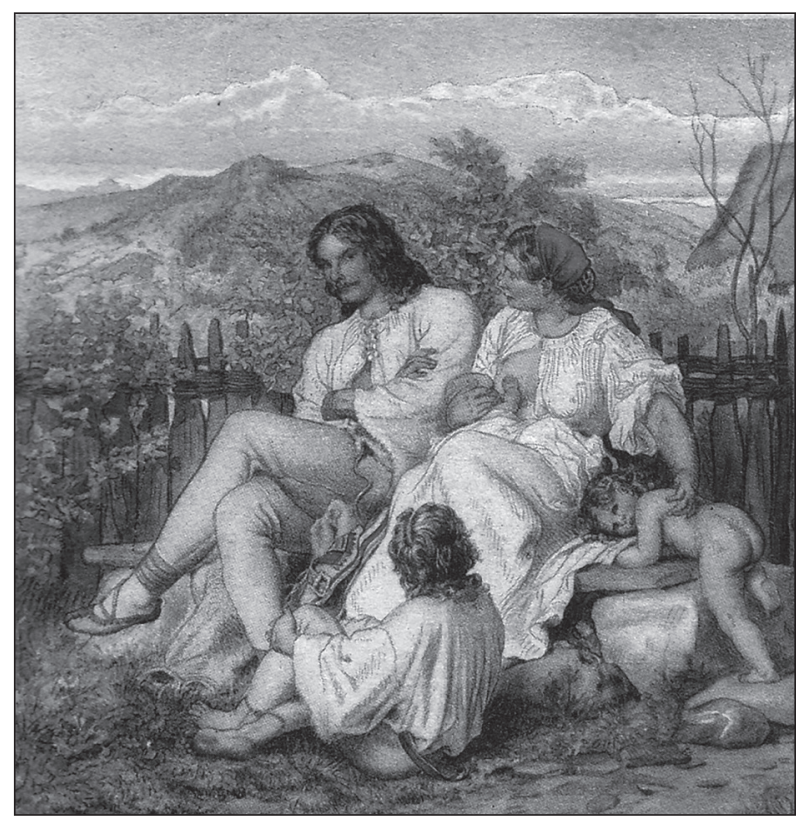

Figure 3. Josef Mánes, Slovanská rodina [Slavic family]. The romanticist epitome of the Slavic rural idyll, sometimes also referred to as the 'Slovak family'. Reproduction of Mánes' painting from the front page of NOVOTNÝ, Miloslav. Mánes a Slovensko [Mánes and Slovakia], 1952. Bratislava: Tvar
Unlike the Balkans, most especially its Adriatic shore and of course Bosnia, on which the modernized and somewhat wealthy Czech bourgeoisie could focus on with oriental exoticism (Š́sTEK 2007), the Slovaks in Hungary were represented with a different kind of romanticism. They were regarded with a hint of primordiality, as accounted for in adaptations of fairy tales by Božena Němcová, in the poetry of Adolf Heyduk and from the paintings and graphic work of Josef Mánes, whose style referred back to the ideas of rigid artistic historicism and romantic idealism (ŽÁKAVEC 1923; cf. Novotný 1952). (Fig. 3)

It seems obvious that the Hungarian parts of the Monarchy were far less visited by the Czechs than the other regions of the multi-ethnic empire, even including the Austrian

Galicia (BLÜMLoví 2008). Surprisingly, public life within the Czech associations and syndicates, then blooming in Vienna, Dubrovnik or even Kiev, were hard to find in Budapest or Pressburg, not to mention Košice or numerous smaller towns in the former Upper Hungarian regions (LIPTÁK 2008). 


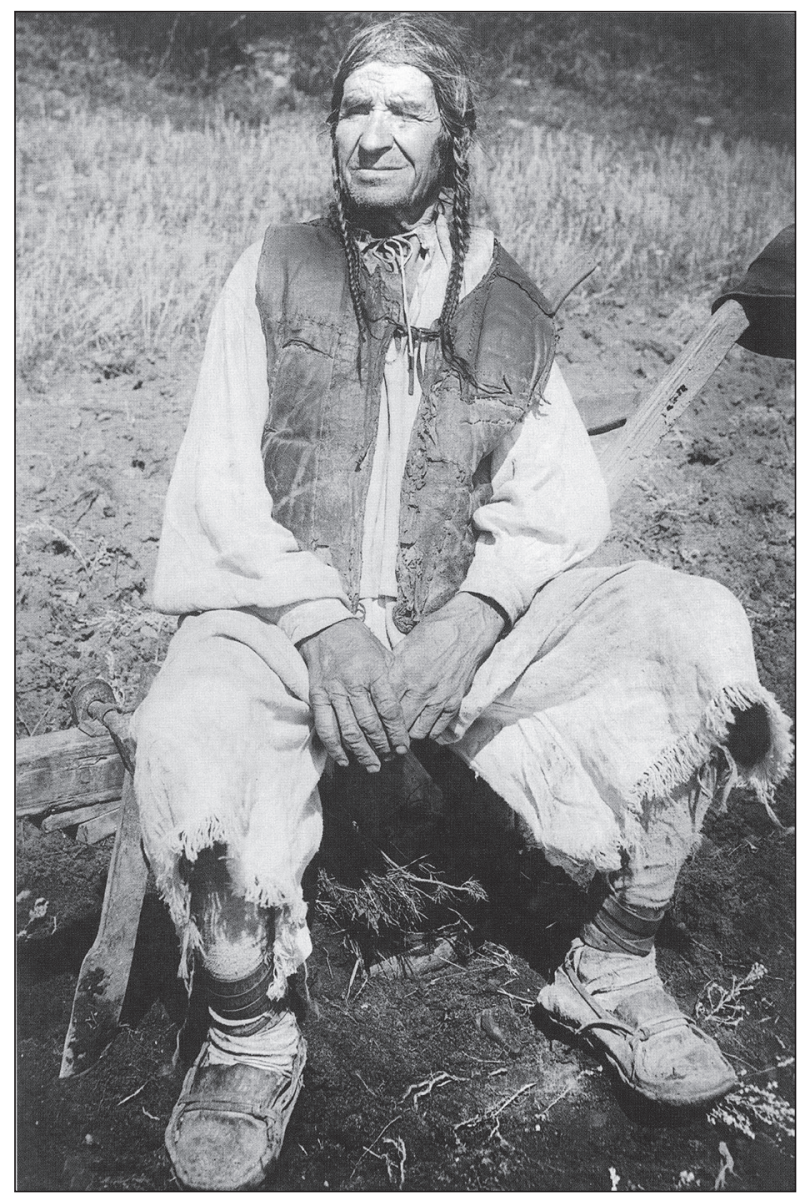

Figure 4. The embodiment of the long-lasting Czech stereotypic vision of a 'real Slovak': Old gazda (shepherd) from Madačka. Photo by Karel Plicka, 1926. Reproduction from HRABUŠICKÝ, Aurel - MACEK, Václav. Slovenská fotografia. Slovak photography, 1925-2000. Moderna Postmoderna - Postfotografia. Modernism - Post-modernism - Post-photography, 2001. Bratislava: Slovanská národná galéria, p. 27 dialects, prevalently Lutherans, and as peasants and shepherds they were mostly rather poor. Here, we arrive at an important paradox, because any Hungarian Slovak who became socially and economically successful, not to say rich, and due to that acquired an urban lifestyle, was usually held by the Czechs as a so called 'Mad'aron', a 'magyarized/ hungarized' person who betrayed his roots, traditions or even his mother tongue (NVČ 1895:84; PiCHLER 2011b; KREKOviČOvÁ 2013:484). Although the community of Slovak intellectuals who kept contacts with the Czech community, such as Andrej Kmet', Pavel Blaho or Dušan Makovický, consisted of small-town priests, lawyers or physicians 
(PICHLER 2011b), who were usually fluent in Hungarian and German, that was not the kind of Slovaks the Czechs wanted. They were not the type of people they visualized in thinking about the Tatra Eagles (Orol tatranský), a people of free Slavic spirit in the Slovakian mountains, bound traditionally to the noble birds-of-prey. (Fig. 4)

The 'real' Slovak, who in the romantic tradition, established during the Metternich era before 1848, was said to be Czech's younger brother, the other branch of the unitary Czechoslavic Nation, should have been a poor, oppressed fellow, though at the same time a proud highlander and shepherd hidden in the woods under or directly in the Tatra mountains. Certainly not a farmer, nor an educated lawyer, and in any case not an urbanized petit-bourgeois with well-established walks of life, living off his small business or even rent (LIPTÁK 2008). Such was the picture of Slovaks in Hungary, commemorated in Czech schools and public places via the aforementioned fairy tales and poetry, especially Ján Kollár's Pan-Slavic poem Slávy Dcera (1824; meaning the Daughter of Slavia, the conjoint, yet desirable Goddess of all Slavic communities and nations) (Kiss Szemán 2008). Such was the picture the Czechs desired to see and behold at the Czechoslavic Ethnographic Exhibition, held in Prague in 1895.

However, - unsurprisingly - it turned out that other than a few engaged activist intellectuals (MiKULOví 2011), no Slovak highlander or shepherd in Upper Hungary seemed to have any notion of the Exhibition, nor did he have any intention to visit it. This was later mentioned in a short story written by Emo Bohún̆, a Slovak journalist and novelist, who lived in Prague during the 1920s and 1930s:

"Several Slovak writers, enthusiastic patriots, a small group of Slovak politicians who had personal contacts with some similar Czechs, they already had their own ideas about Czechs, but the masses of the Slovak people knew only where Prague was, but nothing more. (...) The world in Hungary ended somewhere near Holíč or Skalica, but what was further west in the Czech lands, (...) they had only a fuzzy idea. The thousand years long separation has completely divided us.” (BoнúŇ 1948a:149).

\section{HUNGARIAN SLOVAKS AS WALLACHIANS: FABRICATING A FAMILIAR IMAGE}

However, there really were Slovaks from Hungary present at the Czechoslavic Exhibition in Prague. (Fig.5) The first notable Slovaks were members of the official Slovak delegations, visiting partly in traditional costumes, but mainly (such as the Slovak delegation of teachers in August) dressed as ordinary urban citizens. The most significant of these official visits from Hungarian Slovakia was in July. It was led by the renowned poet and novelist Svetozár Hurban Vajanský, celebrating the $100^{\text {th }}$ anniversary of the birth of Pavel Josef Šafaŕík, an archaeologist, historian and the author of the respected work Slovanské starožitnosti [Slavic Antiquities, 1837; NVČ 1897:516]. Besides the visiting Slovak intellectuals, writers or lawyers from small towns like Turčiansky Sv. Martin (Turóczszentmárton), the common Slovak people from different regions were represented through the exposed artifacts in a very similar way as the year after, in 1896, at the Millennial Exhibition in Budapest, the celebration of the Magyar settlement in the Danube basin. Even some of the exhibition committee collaborators from Hungarian Slovakia, 


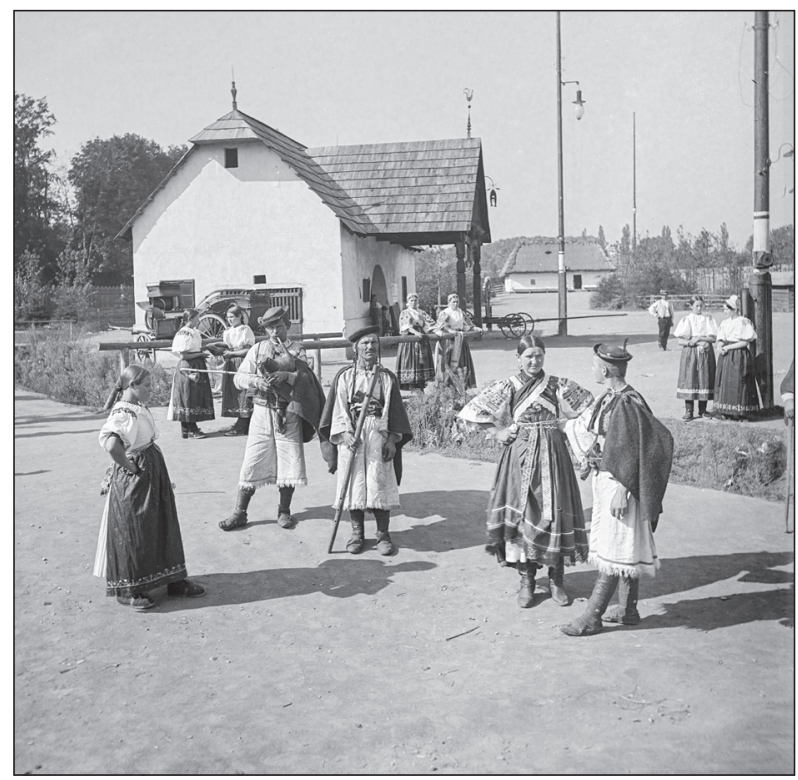

Figure 5. The Detvan party posing in the 'Slovak' part of the Exhibition Village. Photo by F. Krátký, 1895, Scheufler Collection

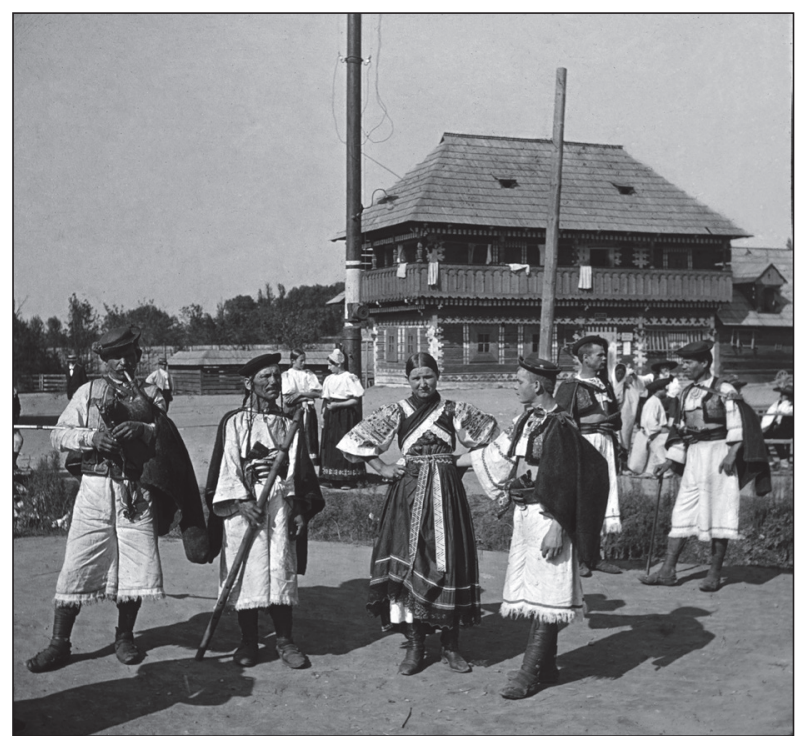

Figure 6. The Detvan party in front of Jurkovič's replica of the Homestead of Čičmany. From the left gajdoš (pipes player) Matuš Šujafanga and fujara player Jura Melik (ostensibly). The names of the others remain unknown. Photo by F. Krátký, detail taken out of a colored positive, 1895, Scheufler Collection who rented their collection of folk artefacts for the Prague exhibition, did quite the same for Budapest a year later. Costumes, embroidery, pottery and other products of folk art or everyday life were there to display the skills of the 'Slovak nationality'. In Prague, these were understood as a tradition of the 'Czechoslavic nation' while in Budapest, it was understood as one of the many parts of the broader Hungarian nation (THIESSE 2007: 173; cf. VARGA 2016:159ff; BARENSCOTT 2010:581-582).

Unlike in Budapest, there were also people from Slovakia on display at the Prague exhibition. This group of individuals was invited and some supposedly even paid by the later renowned Slovak architect Dušan Jurkovič. In fact, Jurkovič 'half-smuggled' them over the border, because of the persuasion that the Hungarian officials would control, follow and investigate any connections between the Czechs and Slovaks with a spectre of Panslavism in their mind (VöRÖs 2017).

The principal part of Jurkovič's fame derived from his ability to incorporate traditional folk motifs into contemporary urban and even aristocratic architecture. Essentially, Jurkovič established his reputation right at the exhibition by designing and erecting a vast number of replicas of 'traditional' houses at the exhibition area (BořUTOVÁ 2009:20-30). His contribution consisted of replicas of numerous buildings. The largest group 


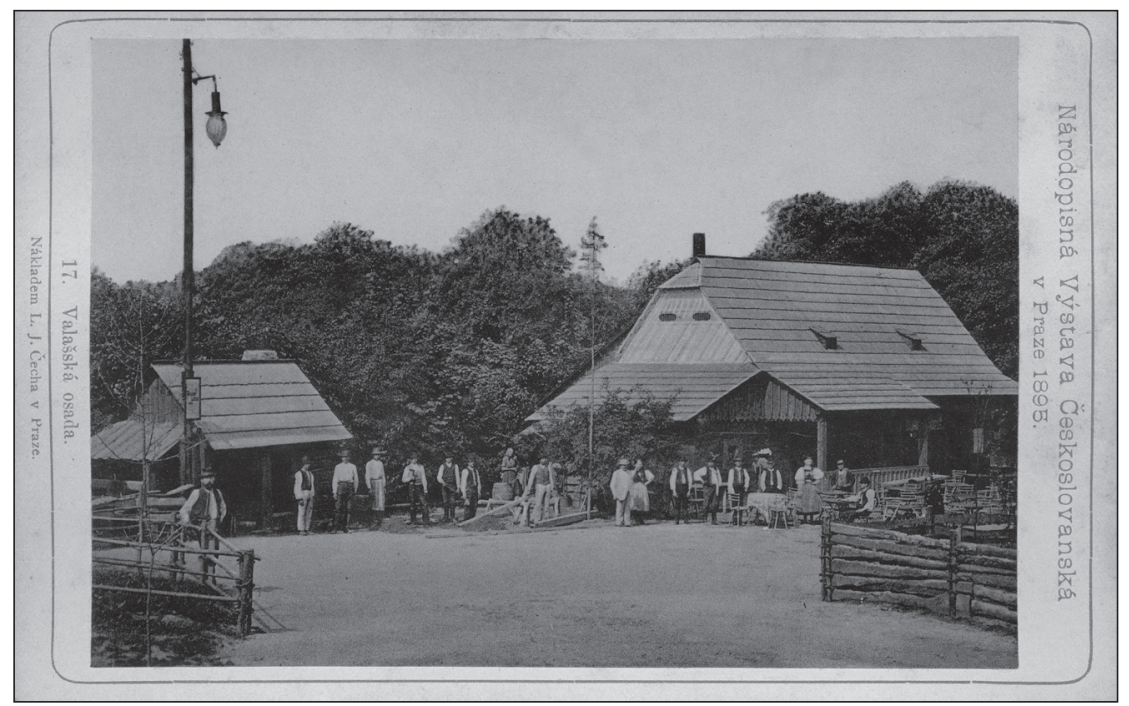

Figure 7. Jurkovič's Wallachian Village; an iconic part of the Exhibition and the "natural" stage for the Slovak reenactment. Cabinet card published by J. L. Čech, 1895, Scheufler Collection

showed a small Wallachian village (Fig.6), including a pub (nicknamed Na posledním groši $i$ [The last Penny]) as an inherent part of the life of the Wallachian people, living in south-central Moravia in the particularly unfruitful and hilly region around Vsetín or Rožnov, bordering the Moravian Slovakia region from the north (NVČ 1897:101).

As stated for the first time by Viennese university scholar of Slovenian origin Franz Miklošič, the inhabitants of this region adopted the habits and lifestyle of the former Coloni Valachales. Individuals settled here, on the westernmost part of the so-called Wallachian colonization during the late Middle Ages up until the early modern era until the $17^{\text {th }}$ century. Formerly called Rutheni or Wallachians, the colonists around the entire Carpathian mountain arch stretching from Romania to Moravia, including the central part of modern day Slovakia, were mostly sheep shepherds, with similar habits as the Wallachians in Romanian Transylvania, Ukraine and Moldova (EHLER 2010). The important point here is that the Wallachian lifestyle greatly overlapped with the Czech vision of 'typical' Hungarian Slovaks, even with the usage of the common words bača for shepherd, bryndza for goat cheese, strun̆ga for fence, čutora for flask, or valaška, the traditional stick with an axe-head, etc. (AlEXANDRU 1974).

It was not inappropriate then, that the visiting company from the Trenčín and Zvolen/ Detva regions, again invited and brought in by Dušan Jurkovič, demonstrated their traditional dances, including swings of the valaškas and jumping over the fireplace, the vatra, (huge campfire) in front of the Wallachian koliba (shepherd's hut), however in fact a 'Moravian' one. Besides the re-constructed Wallachian settlement, Jurkovič also built an imitation of the Čičmanské gazdovstvo (Homestead of Čičmany), the admirable grafted house from the Slovak region of Žilina (Fig7).

As declared at the time by the foremost Slavic archaeologists, the ancestors of Slovaks and other Slavic 'tribes' were believed to have lived in a form of cohabitation called the 


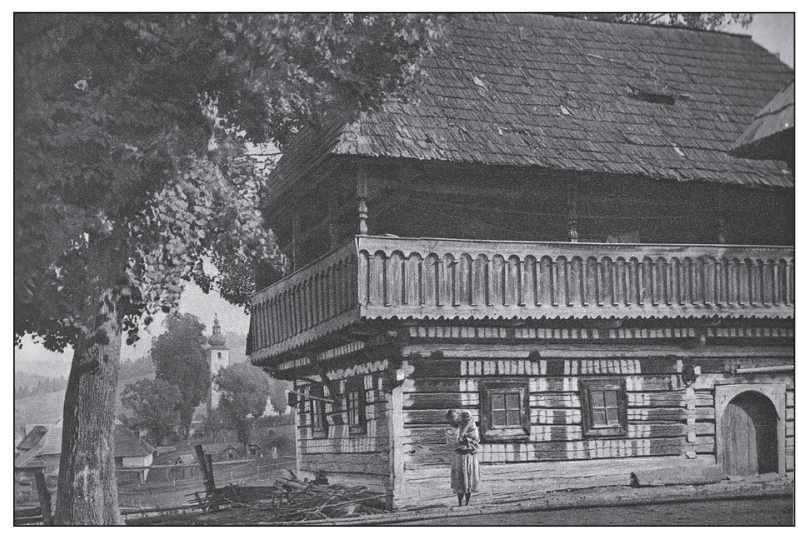

Figure 8. The original homestead in Čičmany of the Žilina region in Slovakia. Photo by Karel Domin, Malebná chalupa v Čičmanech [Picturesque homestead in Čičmany]; taken from the poster series Československo v obrazech. Města, hrady, kroje, zemédělství, prümysl a př́roda. 180 obrazů [Czechoslovakia in Pictures. Towns, Castles, Costumes, Agriculture, Industry and Nature. 180 Posters]. URBAN, Klement (ed.), Prague 1927: plate 130

the 'Slovak' traditional costumes and rituals imaginable (NVČ 1897:518). Arranging a marriage between the two parts of the monarchy remained quite a difficult task due to different Hungarian laws. Thus, the married couples were most likely from Moravian Slovakia. Despite these additions, for the greater part of the exhibition there were only costumed mannequins to be seen. (Fig.8)

\section{MEETING THE 'REAL' BROTHERS: THE RE-COGNIZED 'OTHERNESS' OF SLOVAKS}

Due to the demand for 'real' Slovak live performances at the exhibition, Dušan Jurkovič finally brought in a small company of Hungarian Slovaks (only twenty-six altogether), from the Trenčín and Detva regions to perform during the 'Slovak days', advertised for the first two days of October within and around the buildings in the exhibition area (KVAPIL 1895, BROUČEK et al. 1996:116)

Although they only stayed in Prague for a few days, due to reports in the daily press, such as Svétozor, they delivered a show followed by such applause, that they had to repeat the figures over and over again. Chiefly the Detvans (the group consisted of five men, two women and a girl; ZíBRT 1895c), with their long hair tied in plaits wearing broad trousers, held the attention of regular visitors. Even before their performance they already left some disarray among the Prague citizens, as they shamelessly enjoyed the offers of the famous Prague sights, most especially at local restaurants and pubs. (Fig. 9)

Quite the same can be said about the public reflection of their stay at the exhibition. In Svétozor, the popular Czech petit-bourgeois oriented Friday penny paper, the 


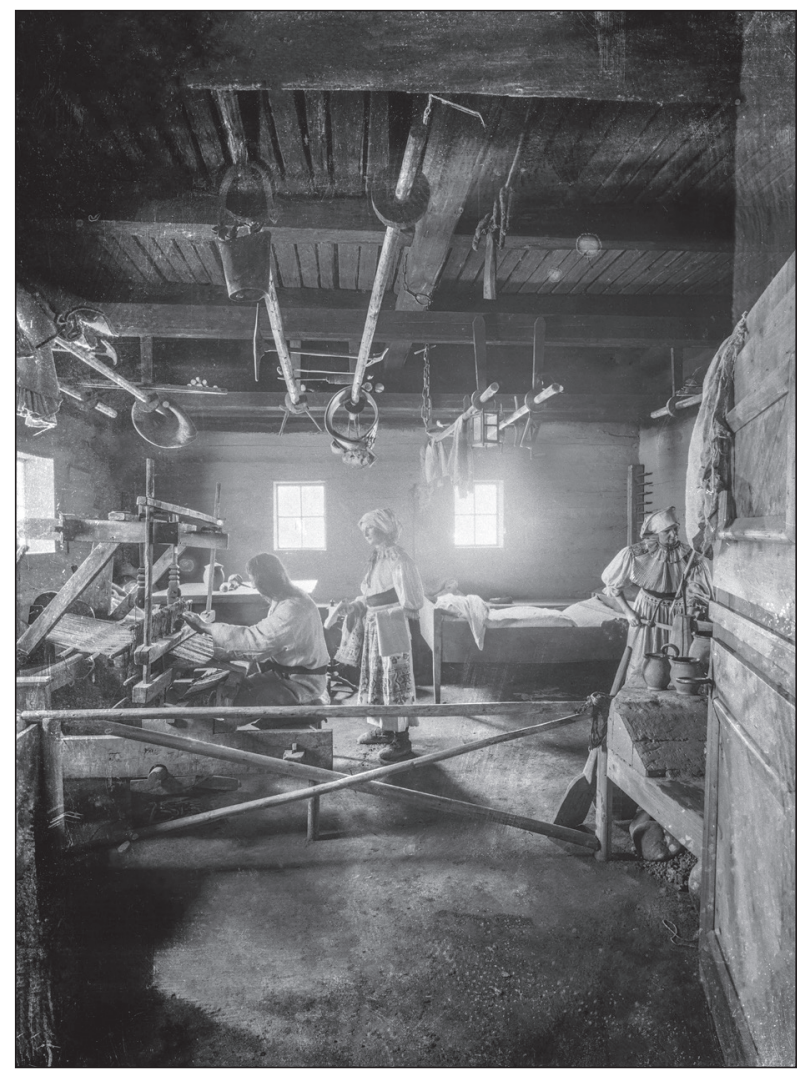

Figure 9. The interior of the Homestead of Čičmany with costumed mannequins depicting scenes of the 'everyday family life of regular Slovaks.' Photo by F. Krátký, half of a stereo image, 1895, Scheufler Collection
Slovaks were represented by the conservative cultural historian Čeněk Zíbrt in an usual romantic stereotype, describing "all the charms of the folk life unspoiled by foreign elements" (ZÍBRT 1895a), with the addition of the photo of the 'typical man from Detva' Jano Kružliak, taken by the architect Jan Koula during his travels to Slovakia - despite the fact that similarly looking individuals, like the gajdoš (pipes player) Matuš Šujafanga and fujara player Jura Melik were among the Slovak visiting group, described by Zíbrt as a četa (platoon; ZíBRT 1895c). Although Zíbrt became familiar with the names of the best Detva dancers (Juro Chamula and Juro Gonda), who performed the impressive odzemok zbojnický (a dance of the mountain outlaws), the only impression the associate professor of cultural history at the Charles University in Prague was able to offer to the readers concerning the Slovak performance besides the description of the costumes and hairstyle, was that: "they surprised us with merry singing and lovely dancing" (ZÍBRT 1895c). This was supported by "the simplest kind of music", creating, along with other performances of the day "a picture of a simple and peculiar life of the Slovakian folk" (ZíBRT 1895c).

Unlike Svétozor, the Young Czech party daily Národní listy, which also dedicated a regular column or even a whole page to the 'chronicle of the exhibition' during the whole period of the event, offered a more structured and critical focus of the Slovak Days. Especially Jaroslav Kvapil, the later foremost playwright and director of the Czech National Theater in Prague, ${ }^{4}$ criticized the preliminary public thrill awakened through the daily press and compared it with the shortcomings of the actual performance of Slovaks in his articles:

4 I hereby wish to express my gratitude to my colleagues, historians of Czech literature Kateřina Bláhová, Martin Hrdina and Michal Charypar, who readily deciphered Kvapil's journalist shortcut alias for me. 


\begin{abstract}
"Well, arrived they had already last week to Prague in a merry humor, with their eyes gazing and their spirits drunk with new impressions - but now: what to do with them? They were offered a few days rest and meanwhile the readers were announced to await something wonderfully unusual. That was why we hurried on Tuesday evening for the amphitheater remembering the performance of the Moravian Slovaks, hoping the crowd would have the opportunity to watch something similarly extraordinary again. Nevertheless it was not so imposing. Yet even then it could have been whimsical, stranger and more illuminative, would there not have been the tension of embarrassment because of the unprepared event" (KvAPIL 1895).
\end{abstract}

According to Kvapil's reference, the first performance of Hungarian Slovaks, held at an open-air amphitheater, ended with disillusion. This occurred not only because the Hungarian Slovaks did not deliver such abundant embroidery and richness of the costumes as the previously acclaimed performances of the Moravian Slovaks had done but mainly because of the lack of an organizational background:

\begin{abstract}
"We were watching a nice scenario in the sand of the arena: a wooden hut, so small you would hit your forehead standing under its roof, a tiny grove around it and in the front a kettle hanging over the fireplace. The costumed figures jumping through the dark and the rhythm of strangely sounding songs echoing in the surrounding buzz. Now comes the fujara with its low and longing voice resembling the wind blowing in the treetops or a fizzing sound of distant waters. But alas! A drum rattled from the nearby pub, the roar of trumpets and the scream of fiddle - and the fujara was gone" (KvaPIL 1895).
\end{abstract}

Therefore the next performance was moved to a theater hall which offered more light and silence, yet much less spontaneity and style, which again resulted in some discontent. However, thanks to Kvapil's dedication to the 'ethnographical question', we also have his reflection on the following action when the afternoon 're-enactment' in the theater transformed itself in Jurkovič's 'Wallachian village' into free, spontaneous celebration:

\begin{abstract}
"Slightly after 9 pm, when the whole area is usually deserted, Hudeček [the initiative Moravian Slovak winehouse-keeper at the exhibition, based in the homestead of Čičmany - note MD] took his Slovak musicians outside to the Wallachian village - and suddenly there was a crowd jostling in front of the pub. Ancient blood ran into the veins of the Detvan lads and the same happened to the others. That was not a performance, that was the truth. The village scenery around, no impresario behind their back - and hey, now the songs resonated, the heels stomped the ground and the fujaras went weeping." (KvaPIL 1895)
\end{abstract}

Although he spent the late evening with other journalists and compatriots, many of whom - due to his claim - "already mastered the art of Slovak dance" and even happened to encounter the female visitors in a more private fashion (KVAPIL 1895). Kvapil did not hesitate to argue that the acting and habits of the visiting Slovak company somehow seemed uncivilized in his conclusion. He even attempted to offer a better way of how to become acquainted with the Slovaks. He suggested the creation of a 'reservation' for them:

\footnotetext{
"Something like that shouldn't have been arranged like a theater over which the curtain was rising and soon falling on it again. It should have been relocated into the exhibition village right
} 
in May, disengaged from any fixed schedule and given full freedom. A colony of the Hungarian Slovaks should have lived somewhere in the corners of the area the way they would like to, quite according to their own habits. The Slovak has to work, or else he will run away. And after the daily routine he should have been given the chance to enjoy the pleasure of the evening. Had that happened they could have been the most interesting corner of the exhibition." (KvAPIL 1895)

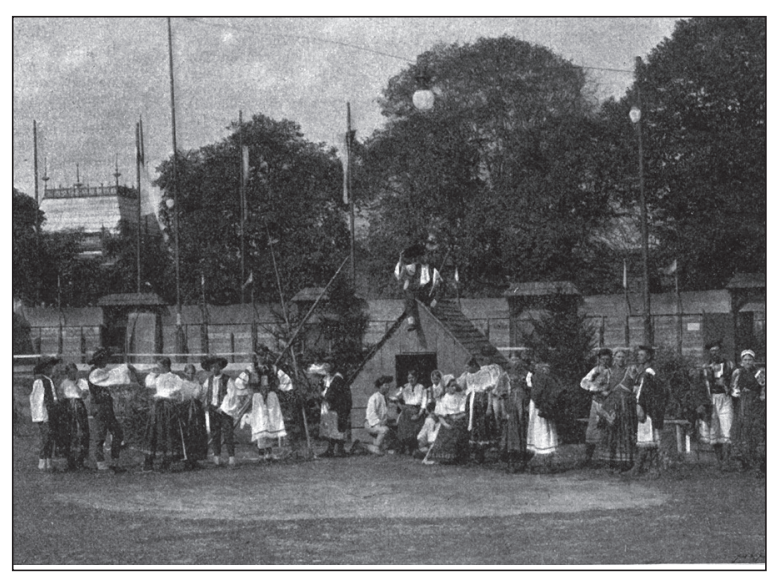

Figure 10. Life of the Slovaks by the artificial koliba shown in the amphitheater at the Czechoslavic Ethnographical Exhibition. Photo by M. Adler, Prague 1895, reprinted in Světozor 1895:587

Despite all the ideals of the Czecho-Slovak brotherhood, in the description of the performance, Kvapil adopted a discourse of difference rather than one of unity. In his personal reflection on the 'natural' spontaneity of the Slovaks, he emphasized discipline through regular work. Based on my research on the response of the public on the exhibition, there was not any similar idea of 'reservation' or cultivation through the working process to be found in connection with any other visiting peasant parties from around the Czech and Moravia. The Prague performance has been obviously, albeit paradoxically reflected even by the insightful and educated journalists as a kind of ethnic show. The rhetoric of Kvapil's report was principally similar to those dedicated to the more 'exotic' shows, like the one delivered by the Hagenbecks and their 'caravan' of Swahili 'Africans' who performed in Prague at the Jubilee Industrial Exhibition in 1891 (HerzA 2016; FiLIPOVÁ 2011:24). ${ }^{5}$

It seems that besides a few stylized reproduced pictures, there are no authentic photos of the Slovak company taken directly 'in action', dancing, singing songs, jumping over the fire and 'being Slovaks' in general (cf. SCHEUFLER 2015). We cannot even prove whether any of them were indeed re-enacting the 'Slovak family' in the Homestead of Čičmany and other expositions instead of the costumed mannequins. Yet - as understood from Kvapil's reference (KVAPIL 1895) - we have evidence of how they acted 'behind the curtain,' drinking and singing in good humor together with their Czech bourgeois admirers who in that moment captured and petrified their shared image of what it meant to be 'Slovak': a brotherly, merry singing, wine- or spirit-loving folk, speaking in the familiar, yet uncommon dialect and living miserably under the threat of Hungarization.

There were many opportunities for such an experience. Beside the aforementioned Wallachian pub, numerous other pubs and restaurants, even a Slovak wine cellar from the Moravian Slovakia (NVČ 1897:107), constituted an inherent and important

\footnotetext{
5 Here, I express my thanks to Filip Herza for his insightful discussion on the topic.
} 


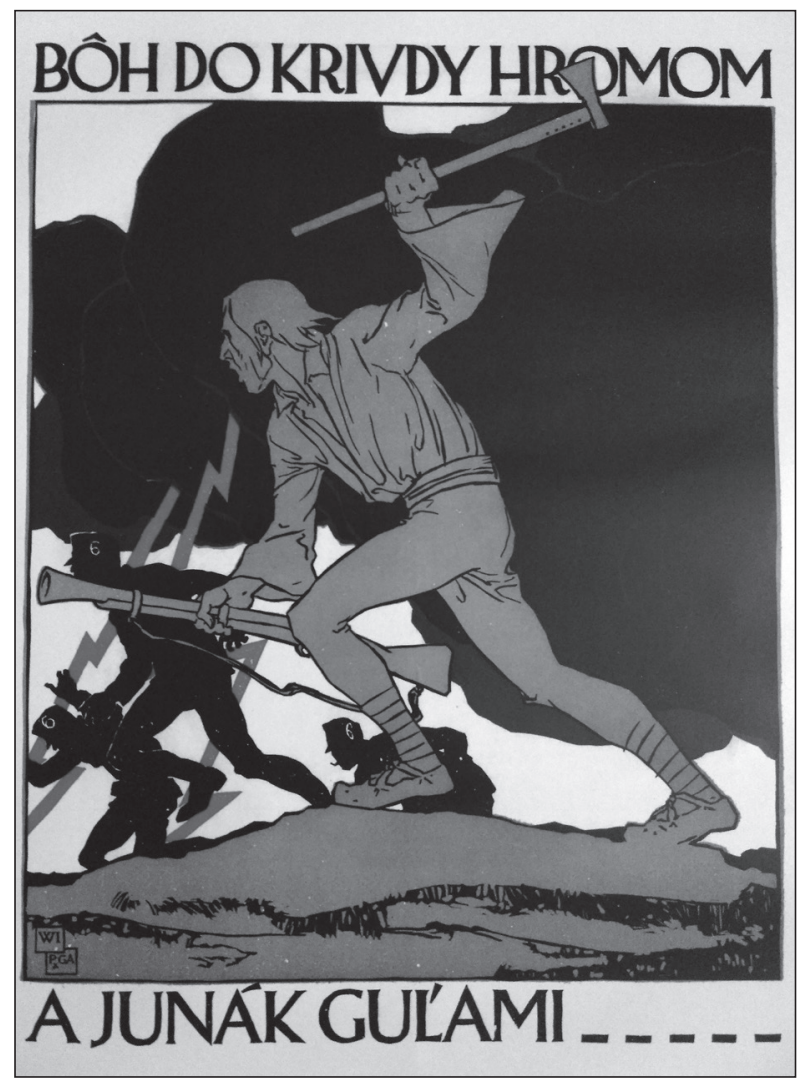

Figure 11. God punishes treason by thunder, the brave man by bullets. A Czechoslovak war propaganda conscription poster by Czech painter Vojtěch Preissig (1918). The painter uses the widespread Czech visual stereotype of Slovaks: Slovak 'trooper,' the elderly highlander dressed in a traditional shepherd outfit, grasping valaška and an ancient gun while successfully fighting back the Austro-Hungarian army. Printed by School of Printing and Graphic Arts of Wentworth Institute, Boston (Mass., USA), ordered by the Czechoslovak Recruiting Office (Tribune Building, New York). Reproduction from the 1918 100th Anniversary Calendar (September), issued by the Municipality of Prague 6, 2018. Author's archive

Štefánik, later the organizer of the Czechoslovak volunteer army (the so called legions) in revolutionary Russia (Fig. 11), and the physician Vavro Šrobár, later the first Czechoslovak Minister entrusted to the Administration of Slovakia in 1919 and a longtime member of the Czechoslovak Cabinet, whose career symbolized the Slovak share on the idea of the politics of Czechoslovakism in the public sphere, even after the dawn of the Communist era in February of 1948.

part of the exhibition. In the Slovak case, the pub was by all means perceived as their main and most important stage. Even with the aforementioned spontaneous encounters in the restaurants, the Slovak reenactment at the exhibition answered the older, romantic image of the 'Eastern brothers' in every possible way, thus strengthening and re-creating a widespread stereotype.

Some might say that there is a danger in overestimating or even exaggerating the influence of such an image. However, this notion was further supported by the numerous communities of Prague-based Slovak university students, including their public activities organized by the table societies like the well-known Detvan society. The leading members of the Detvan were mostly influenced by the idea of Czecho-Slovak reciprocity, as it was understood by Tomáš Garrigue Masaryk, who was a professor of philosophy at the Czech section of the Charles-Ferdinand University in Prague at the time (Hollý 2011). On account of his lectures and books, his ideas were accepted by the founding members of Detvan society. It influenced individuals such as the astronomer Milan Rastislav 


\section{CONCLUSION: CZECHOSLAVISM INTO CZECHOSLOVAKISM}

The described blend of Slovak participation in the ethnographic exhibition in Prague as well as the older poetic images of the Slovaks as primordial folk, represents a great portion of the images of 'otherness' of the 'Eastern brothers.' In the late 1890s, the Czech re-cognition of the Hungarian Slovaks did not emphasize the former intellectual efforts and political actions of the leading Slovak romantic nationalist L'udevít Štúr and his compatriots, who despite the Czech discourse of linguistic unity consistently demonstrated their efforts to enforce the practical use of Slovak language as the individual linguistic phenomenon in literature and public administration (MAXWELL 2009:117ff). It resembled the collective picture of rural, peasant folk, in a way very similar to the depiction of the Slovaks offered in the Hungary-dedicated volumes of Österreich-Ungarische Monarchie im Wort und Bild [Austro-Hungarian Monarchy described and depicted], or the so called Kronprinzenwerk [The Crown Prince's Work; nickname emphasizing the initial role and contribution of Crown Prince Rudolf von Habsburg on the collective multi-volume project] (KiLIÁNOví et al. 2001).

Unlike the Hungarian reception, the Czech one was closely bound to the image of the 'suffering of the Slovaks,' through the pressure of Hungarization. It was omnipresent on the pages of the Czech journals and daily press (HARNa 2014; PelČÁKoví 2004; Stehlík 2009), in the pro-Slovak activist publications of the foremost Czech 'slovakophile' Karel Kálal (HoLLÝ 2013) and even in the influential essays of Tomáš Garrigue Masaryk (HoLLÝ 2011:46-52). This public image principally lasted from the late 1890s until the disintegration of the Austro-Hungarian Empire and the establishment of Czechoslovakia in 1918. As I attempted to put forward above, the Czechoslavic ethnographical exhibition represents an important moment in the process of its petrification. This is apparent in the short stories by the aforementioned novelist Emo Bohún. Remembering his participation in the first official visit of the 'Slovak intelligentsia' to Prague in 1920, he noted: "I am afraid we have somehow disappointed the good people of Prague. They expected strapping tinkers holding valaškas and wearing greasy hats - and here come people in black dresses sewn by good tailors, with hard collars and ties..." (BoHúŇ 1948b:157158). The described Czech re-cognition and fixed misinterpretation of the 'otherness' of Slovaks, influenced by the public response to the visit in Prague in 1895, resulted in a wave of mutual disillusions and misunderstandings after 1918 (NURMI 1999; MAXWELL 2009:166ff; RYCHLíK 2017) soon after the idea of a single, unified 'Czechoslovak nation' faced the arena of everyday political life of Czechoslovakia (for a more detailed focus on the issue see related chapters in KOPEČEK et al. 2019). ${ }^{6}$

${ }_{6}$ „This paper is an outcome of a standard grant project GAČR 19-03474S Evolucionalismus, nacionalismus a rasismus $v$ české a slovenské vědě (1882-1948): dialog mezi sociálněvědními obory a biologii [Evolutionalism, Nationalism and Racism in Czech and Slovak Science (18821948). A Dialogue between Social Science and Biology] supported by the Grantová agentura České republiky [Czech Science Foundation] and administered by the Centre for the History of Sciences and Humanities - Institute of Contemporary History, Czech Academy of Sciences.” 


\section{REFERENCES CITED}

Aвbattista Guido

2015a Alien Humans on Display. "Time Machines" and the Visual and Temporal Appropriation of Human Diversity (draft). Available online: https://www. academia.edu/18131525/Alien_Humans_on_Display._Time_Machines_and the_Visual_and_Temporal_Appropriation_of_Human_Diversity (accessed July 20, 2019).

$2015 b$ Beyond the 'Human Zoos.' Exoticism, Ethnic Exhibitions and the Power of the Gaze. In Fontana, Giovanni Luigi - Pellegrino, Anna (eds.) Esposizioni Universali in Europa. Attori, pubblici, memorie tra metropoli e colonie, 18511939. [Ricerche storiche 45(1-2)], 207-218. Firenze: Polistampa.

ABbatTisTa Guido - IANNUZZI Giulia

2016 World Expositions as Time Machines: Two Views of the Visual Construction of Time between Anthropology and Futurama. World History Connected 13(3). Available online: http://worldhistoryconnected.press.illinois.edu/13.3/ forum_01_abbattista.html (accessed July 20, 2019).

AlEXANDRU, Theodora

1974 Lexikální prvky rumunského původu ve Slovníku spisovného jazyka českého [Lexical Elements of Romanian Origin in the Dictionary of Standard Czech]. Naše ř ̌č 57(3):142-148. Avalilable online: http://nase-rec.ujc.cas.cz/archiv. php?lang=en\&art=5773 (accessed July 20, 2019).

BARENSCOTT, Dorothy

2010 Articulating Identity through the Technological Rearticulation of Space: The Hungarian Millennial Exhibition as World's Fair and the Disordering of Finde-Siècle Budapest. Slavic Review 69(3):571-590.

BLÜMLOVÁ, Dagmar

2008 Slovensko z českého pohledu let 1891-1914, aneb O trojím (slovenském) lidu řeč [Slovakia from the Czech Perspective in the Years 1891-1914, or a Talk about the Three Forms of (Slovak) People]. In Pospíšil, Ivo (ed.) Slovensko mimo Slovensko $=$ Slovensko mimo Slovenska, 19-29. Brno: Masarykova univerzita.

BoHúŇ, Emo

1948a Október 1918. In BoHúŇ, Emo: Zaprášené histórie, 148-156. Bratislava: Obrod.

1948b Český paprikáš [Czech Pepper Stew/Paprikás/]. In BoHÚŇ, Emo: Zaprášené histórie, 157-164. Bratislava: Obrod.

BoŘutoví, Dana

2009 Architekt Dušan Samuel Jurkovič [Dušan Samuel Jurkovič. An architect]. Bratislava: Slovart.

BROUČEK, Stanislav

1984 K česko-slovenským stykům v národopise v první polovině devadesátých let 19. století [Towards the Czech-Slovak Relation in Ethnography in the Mid1890s]. Slovenský národopis 32(4):605-617. 
2015 Účast Slováků a Slovenska na př́pravách Národopisné výstavy českoslovanské 1895 [The Participation of the Slovaks in Preparation of the Czechoslavic Ethnographic Exhibition 1895]. Prameny a studie 56:45-58.

BROUČEK, Stanislav - PARGAČ, Jan - Sochorová, Ludmila - ŠTĚPÁNOvÁ, Irena

1996 Mýtus českého národa aneb Národopisná výstava českoslovanská 1895 [The Myth of the Czech Nation or the Czechoslavic Ethnographic Exhibition 1895]. Praha: Littera Bohemica.

BRUBAKER, Rogers

2015 Nationalism, Ethnicity and Modernity. In BrubaKer, Rogers: Grounds for Difference, 147-156. Cambridge, Mass. - London: Cambridge University Press.

Demski, Dagnosław - Sz. Kristóf, Ildikó - Baraniecka-Olszzewska, Kamila (eds.)

2013 Competing Eyes. Visual Encounters with Alterity in Central and Eastern Europe. Budapest: L'Harmattan.

DUCHÁČEK, Milan

2014 Ćeskoslovenský národ jako ideál a jako touha [Czechoslovak Nation as Ideal and as Desire]. In Hrdina, Martin - Piorecká Kateřina (eds.) Historické fikce a mystifikace v české kultuře 19. století, 185-197. Prague: Academia.

2016 Deset tezí k (dis)kontinuitě československé etnografie před rokem 1945 [Ten Theses on the (Dis)Continuity of Czechoslovak Ethnography before 1945]. In WoITsch, Jiří - JŮNOvá Macková, Adéla et al. (eds.) Etnologie v zúženém prostoru, 37-70. Praha: Etnologický ústav Akademie věd ČR v. v. i.

EHLER, Edvard

2010 Y chromosomálni polymorfismy v české populaci se zaměrením na moravské Valašsko: evolučně antropologická studie [Y Chromosomal Polymorphisms in the Czech Population with a Focus on Moravian Wallachia: A Study in Evolutionary Anthropology], PhD Thesis, Department of Anthropology and Genetics, Faculty of Science, Charles University, Prague. Available online: https://is.cuni.cz/webapps/zzp/detail/138824/ (accessed July 20, 2019).

FABIAN, Johannes

2001 Remembering the Other: Knowledge and Recognition. In FabIAN, Johannes - BAt, Mieke - DE VRIES, Hent (eds.) Anthropology with an Attitude. Critical Essays, 158-178. Stanford: Stanford University Press.

2006 The Other revisited. Critical afterthoughts. Anthropological Theory 6(2):139-152. FiLIPové, Marta

2011 Peasants on display: The Czechoslavic Ethnographic Exhibition of 1895. Journal of Design History 24(1):15-36.

HaRna, Josef

2014 Slovakofilství českých 'realistů' v předvečer první světové války [Slovakophilism of the Czech 'Realists' on the Eve of the First World War]. Moderní dějiny: časopis pro dějiny 19. a 20. století = Modern History. Journal for the History of the $19^{\text {th }}$ and $20^{\text {th }}$ Century 22(2):39-69. 
HASLINGER, Peter

2002 Die Slowakei - Neue Impulse der Forschung: Geschichtsschreibung in und über die Slowakei (19./20. Jahrhundert). Bohemia: Zeitschrift für Geschichte und Kultur der böhmischen Länder 43(2):465-470. Available online: http://ostdok. $\mathrm{de} / \mathrm{id} / 9379241 / \mathrm{ft} / \mathrm{bsb} 00044880$ ?page $=480 \& \mathrm{c}=$ solrSearchOstdok (accessed July 20, 2019).

2010 Nation und Territorium im tschechischen politischen Diskurs 1880-1938. München: R. Oldenbourg.

HERZA, Filip

2016 Black Don Juan and the Ashanti from Asch: Representations of 'Africans' in Prague and Vienna, 1892-1899. In JŮnoví Macková, Adéla - Storchové, Lucie - JŮn, Libor (eds.) Visualizing the Orient: Central Europe and the Near East in the $19^{\text {th }}$ and 20 $0^{\text {th }}$ Centuries, 95-106. Prague: Academy of Performing Arts in Prague (AMU), Film and TV School of Academy of Performing Arts in Prague (FAMU).

HLAvaČKa, Milan - KolÁŘ, František

1991 Češi, Němci a jubilejní výstava 1891 [Czechs, Germans and the 1891 Anniversary Exhibition]. Český časopis historický $=$ The Czech Historical Review 89(4):493-518.

HolLÝ, Karol

2011 Ponímanie histórie a inštrumentalizácia obrazov minulosti v národnej ideológii Tomáša G. Masaryka na prelome 19. a 20. storočia [Understanding the History and Instrumentalization of the Past in the National Ideology of Tomáš G. Masaryk at the Turn of the $20^{\text {th }}$ Century]. Déjiny - teorie - kritika 8(1):35-59.

2012 Formovanie národnej ideológie českých slovakofilov (1880-1881) a jej hodnotenie v rámci slovenskej národoveckej society [Formation of the National Ideology of Czech Slovakophiles (1880-1881) and its Evaluation within the Slovak National Society]. In HRADECKÝ, Tomáš (ed.) České, slovenské a československé dějiny 20. století 7, 11-22. Hradec Králové: Historický ústav Filozofické fakulty Univerzity Hradec Králové.

2013 Východiská slovakofilskej ideológie K. Kálala na prelomu 19. a 20. storočia [The Basis of the Slovakophile Ideology of K. Kálal at the Turn of the $19^{\text {th }}$ and $20^{\text {th }}$ Centuries]. In HRADECKÝ, Tomáš (ed.) České, slovenské a československé dějiny 20. století 8, 285-296. Ústí nad Orlicí: Oftis.

Hroch, Miroslav

2015 European Nations: Explaining their Formation. London - New York: Graham. JERVIS, John

1999 Transgressing the Modern. Explorations in the Western Experience of Otherness. Oxford-Malden MT: Blackwell.

Jobs, Sebastian - MaCKEnTHun, Gesa

2011 Introduction. In Jobs, Sebastian - Mackenthun, Gesa (eds.) Embodiments of Cultural Encounters, 7-20. Münster - New York - München - Berlin: Waxmann.

JURČIŠINOví, Naděžda

2000 Spolupráca Českoslovanskej jednoty so slovenskými dôverníkmi pri rozvíjaní kultúrnych vzt’ahov medzi Čechmi a Slovákmi [The Cooperation 
between the Sections of the Czecho-Slavic Unity Society with the Slovak Confidants in the Development of the Relations between the Czechs and the Slovaks]. Česko-slovenská historická ročenka 2000, 185-198. Brno: Masarykova Univerzita v Brně.

2006 Podiel odborov Česko-slovanskej jednoty na rozvíjaní česko-slovenských kultúrnych vzt'ahov [The Share of the Sections of the Czecho-Slavic Unity Society on the Development of the Czecho-Slovak Relations]. Acta historica Neosoliensia 9:114-123.

Kiliánoví, Gabriela - Popelková Katarína - VRzGulová Monika - ZAJONC Juraj

2001 Slovensko a Slováci v diele „Rakúsko-Uherská monarchia slovom a obrazom“ [Slovakia and the Slovak in the Work Austro-Hungarian Empire in Words and Pictures]. Slovenský národopis 49(1):5-31.

Kiss SzEMÁN, Róbert

2008 Velký kreátor Kollár. Grundlage VII. Kollárovo dílo v nás [Ján Kollár, the Great Creator. Grundlage VII. Kollár's Work in Our Minds]. In ŘEPA, Milan (ed.) 19. století v nás: modely, instituce a reprezentace, které přetrvaly, 393402. Praha: Historický ústav AVČR.

KodAJová, Daniela

2009 Slovenský l’ud ako mýtus česko-slovenských vzt’ahov [Slovak People as the Myth of Czecho-Slovak Relations]. In GonĚc, Vladimír (ed.) Česko-slovenská historická ročenka 2008, 53-67. Brno: Academicus - Coprint.

KONRÁD, Ota

2011 Německé bylo srdce monarchie... Rakušanství, němectví a střední Evropa v rakouské historiografii mezi válkami [German Was the Heart of the Monarchy... Austrianism, Germanism and Central Europe in Austrian Historiography between the World Wars]. Praha: Nakladatelství Lidové Noviny.

KopečeK, Michal - Mervart, Jan - Hudek, Adam et al.

2019 Čechoslovakismus/Czechoslovakism. Praha: Nakladatelství Lidové noviny (TBA, collective monography in print, English version of the book also expected).

Krekovičová, Eva - PANczovÁ, Zuzana

2013 Visual Representations of Self and Others: Images of the Traitor and the Enemy in Slovak Political Cartoons, 1861-1910. In DEMSKI, Dagnosław - Sz. Kristóf, Ildikó - BaraniecKA-OlszewsKa, Kamila (eds.) Competing Eyes: Visual Encounters With Alterity in Central and Eastern Europe, 462-487. Budapest: L'Harmattan.

KVAPIL, Jaroslav

1895 (= vap.) Národopisná výstava českoslovanská V Praze, dne 6. října 1895 [Czechoslavic Ethnographic Exhibition in Prague, October 6, 1895]. Národni listy 35(276):5.

LEERSSEN, Joep

2006 Nationalism and the Cultivation of Culture. Nations and Nationalism 12(40):559-578.

LEMMEN, Sarah

2013 Noncolonial Orientalism? Czech Travel Writing on Africa and Asia around 1918. In Hodkinson, James - Walker, John - MAzumdar, Shaswati - 
Feichtinger, Johannes (eds.) Deploying Orientalism in Culture and History. From Germany to Central and Eastern Europe, 209-227. Rochester, NY: Camden House.

LIPTÁK, L’ubomír

2008 Malé mesto a velký svet [Small Town and the Big World]. In LIPTÁK, Lubomír:

Nepre(tr)žité dejiny. Výber článkov, úvah a štúdií, 69-75. Bratislava: Q111.

Lozoviuk, Petr

2001 Etnografie jako národní věda [Ethnography as National Science]. In KAISERová, Kristina - KunšTát, Miroslav (eds.) Hledání centra. Vědecké a vzdělávací instituce Němců v Čechách v 19. a první polovině 20. století, 59-98. Ústí nad Labem: Albis international.

2008 Interethnik im Wissenschaftsprozess. Deutschsprachige Volkskunde in Böhmen und ihre gesellschaftlichen Auswirkungen. Leipzig: Lepiziger Universitätsverlag.

MACURA, Vladimír

1997 Chaloupka - projekt idyly [The Cottage - An Idyllic Project]. In Hodroví, Daniela - Hrbata Zdeněk - Kubínová, Marie - MacurA, Vladmír (eds.) Poetika míst. Kapitoly z literární tematologie, 44-61. Praha: H\&H.

MAXWELL, Alexander

2009 Choosing Slovakia: Slavic Hungary, the Czechoslovak Language and Accidental Nationalism. London - New York: Tauris Academic Studies.

MJARTAN, Ján

1955 Jubileum česko-slovenskej spolupráce v národopise [Jubilee of the CzechoSlovak Cooperation in the Field of Ethnography]. Slovenský národopis/Slovak Ethnology 3(4):450-473.

Mikuloví, Marcela

2011 Pražská Všeslovanská výstava v slovenskom „osvietenom“ cestopise (Terézia Vansová: Pani Georgiadesová na cestách) [The Prague Allslavic exhibition on the pages of a Slovak "enlightened" journal: Terésia Vansová's Mrs. Georgiades's Travels]. In Pospíšil, Ivo - Zelenková, Anna (eds.) Literární historiografie a česko-slovenské vztahy, 63-70, Brno: Tribun EU. Available online: https://digilib.phil.muni.cz/handle/11222.digilib/134230 (accessed July 20, 2019).

NiEDERLE, Lubor (ed.)

1918-1922 Národopis lidu českoslovanského I. - Moravské Slovensko I-II. [Ethnography of the Czechoslavic People]. Praha: Národopisná společnost českoslovanská a Archaeologická komise České akademie věd a umění.

NovotnÝ, Vladimír

1952 Mánes a Slovensko [Mánes and Slovakia]. Bratislava: Tvar.

NuRMI, Ismo

1999 Slovakia, a Playground for Nationalism and National Identity. Manifestations of the National Identity of the Slovaks, 1918-1920. Helsinki: Suomen Historiallinen Seura.

NVČ

1897 Národopisná výstava českoslovanská v Praze 1895 [Czechoslavic Ethnographic Exhibition in Prague 1895]. KLusáčEK, Karel (ed.) Praha: Jan 
Otto 1897. Available online: http://www.nulk.cz/ek-obsah/narvystava/index. ODKAZ NVČ htm (accessed July 20, 2019).

2015 Odkaz Národopisné výstavy českoslovanské 1895 v oblasti etnografie, muzejnictví a památkovépéče [The Heritage of 1895 Czechoslavic Ethnographic Exhibition in Ethnography, Museums and Conservation]. (= Prameny a studie 56). Available online: http://nzm.cz/multimedia/uploads/2016/09/pas_56.pdf (accessed July 20, 2019).

OKURKA, Tomáš

2009 Všeobecné výstavy v Čechách na přelomu 19. a 20. století jako jeviště českoněmeckého soupeření a hospodářského nacionalismu [General Exhibitions in Bohemia at the Turn of the $20^{\text {th }}$ Century as a Stage of Czech-German Rivalry and Economic Nationalism]. In HÁLEK, Jan - JANČí́, Drahomír - KubŮ, Eduard (eds.) O hospodářskou národní državu: úvahy a stati o moderním českém a německém nacionalismu v českých zemích = For economic national possessions: reflections and studies in modern Czech and German nationalism in the Czech lands, 47-57. Praha: Karolinum.

2016 'Vynikajici hospodářský a národni čin'. Průmyslové a všeobecné výstavy v Čechách 1891-1914. Aktéri a jejich motivace ["Excellent Economic and National Deed". Industrial and General Exhibitions in Bohemia 1891-1914. Actors and Their Motivation]. Ústí nad Labem: Univerzita Jana Evangelisty Purkyně v Ústí nad Labem - Praha: Scriptorium.

Pelčáková, Dagmar.

2004 Česko-slovenská vzájomnost’: jej chápanie v okruhu spolupracovníkov Českoslovanskej jednoty (1896-1914) [Czech-Slovak Mutuality: its understanding in the circle of collaborators of the Czechoslavic Unity Association (1896-1914)]. In Česko-slovenská historická ročenka 2004, 237250. Brno: Masarykova Univerzita v Brně.

PENNY, Glenn H.

2002 Objects of Culture. Ethnology and Ethnographic Museums in Imperial Germany. Chapel Hill - London : The University of North Carolina Press.

PICHLER, Tibor

2011a Etnos a polis. Zo slovenského a uhorského politického myslenia [Etnos and polis. Issues concerning the Hungarian political thought]. Bratislava: Kalligram.

2011b Uhorská politická kultúra a slovenské národovecké myslenie [Hungarian political culture and the Slovak nationalist thought]. In IvANIČKové, Edita et al. (eds.) Kapitoly z histórie stredoeurópského priestoru v 19. a 20. storočí. Pocta k 70-ročnému jubileu Dušana Kováča, 200-212. Bratislava: Historický ústav SAV.

PoDOLÁK, Ján

1970 Národopisná výstava československá a Slovensko [Czechoslavic Ethnographic Exhibition and Slovakia]. Slovenský národopis 18(4):585-594.

RYCHLÍK, Jan

2017 Idea čechoslovakismu versus dotváření svébytného slovenského politického národa v první Československé republice [The idea of Czechoslovakism 
versus the completion of a distinctive Slovak political nation in the first Czechoslovak Republic]. Studia historica Nitriensia 21 (2):431-440.

SCHEUFLER, Pavel

2015 Fotografové a Národopisná výstava českoslovanská [Photographers and the Czechoslavic Ethnographic Exhibition]. Prameny a studie 56:80-100. Available online: http://nzm.cz/multimedia/uploads/2016/09/pas_56.pdf (accessed July 20, 2019).

Š́́sTEK, František

2007 'Our Brothers from the South'. Czech Images of Montenegro and the Montenegrins before 1918 as an Example of a Positive Discourse on the Balkans. In BABKa, Lukáš - Roubal, Petr (eds.) A new generation of Czech East European studies, 177-188. Prague: National Library of the Czech Republic/Slavonic Library.

STEHLÍK, Michal

2009 Češi a Slováci 1882-1914. Nezřetelnost společné cesty [Czechs and Slovaks 1882-1914. Vagueness of the common path]. Praha: Togga.

ThIESSE, Anne-Marie

2007 Vytvárení národnich identit v Evropě 19. až 20. století [Creation of the European Nations during the $18^{\text {th }}-20^{\text {th }}$ Century]. Brno: Centrum demokracie a kultury.

URBAN, Zdeněk

1972 Problémy slovenského národního hnuti na konci 19. století [Problems of the Slovak National Movement at the End of the $19^{\text {th }}$ Century]. Praha: Univerzita Karlova.

VAŘEKA, Josef - Frolec, Václav

2007 Lidová architektura. Encyklopedie [Cyclopedia of Vernacular Architecture]. 2nd ed. Praha: Grada.

VARGA, Bálint

2016 The Monumental Nation. Magyar Nationalism and Symbolic Politics in Finde-siècle Hungary. New York NY - Oxford: Berghahn.

VöRös, László

2017 “Veszedelmes panszlávok.”A magyaruralkodó elitképe a szlovák mozgalomról a 19-20. század fordulóján ["Dangerous Panslavs" Hungarian Political Elites and Their View on the Slovak National Movement at the Break of the $19^{\text {th }}$ and $20^{\text {th }}$ Century]. In Szarka, László (ed.) Párhuzamos nemzetépítés, konfliktusos együttelés: Birodalmak és nemzetállamok a közép-Európai régióban (18481938), 159-192. Budapest: Országgyülés Hivatala.

WOLFREYS, Julian

2008 The Urban Uncanny. The City, the Subject, and Ghostly Modernity. In Collins, Jo - Jervis, John (eds.) Uncanny Modernity: Cultural Theories, Modern Anxieties, 168-180. Basingstoke - New York NY.

ŽÁKAVEC, František

1923 Dílo Josefa Mánesa II. - Lid československý [The Work of Josef Mánes. Volume 2: The Czechoslovak People]. Praha: Jan Štenc. 
ZíBRT, Čeněk

1895a Moravské slavnosti na NVČ [Moravian Celebrations at the Czechoslavic Ethnographic Exhibition]. Světozor 29(41):492.

1895b Slovenská krajkářka $\mathrm{v}$ tvrdoňské chalupě na Národopisné výstavě českoslovanské [Slovakian Lace-Maker in the House of Tvrdonice at the Czechoslavic Ethnographic Exhibition]. Světozor 29(47):564.

1895c Lidové slavnosti Uherských Slováků na Národopisné výstavě českoslovanské [Folk Performance of the Hungarian Slovaks at the Czechoslavic Ethnographic Exhibition]. Světozor 29(49):588.

Milan Ducháček, Ph.D., researcher at the Centre for the History of Sciences and Humanities - Institute for Contemporary History, Academy of Sciences of the Czech Republic; lecturer at the Department of History of the Faculty of Science, Humanities and Education of the Technical University of Liberec; he also teaches history at Lauder Schools in Prague. His main area of interest covers the intellectual and cultural history of the modern era and the history and theory of humanities, especially historiography and ethno/anthropology. Author of the monograph Václav Chaloupecký. Hledáni československých dějin [Václav Chaloupecký. The Search for Czechoslovak History] (2014), co-author and co-editor of the collective monograph Václav Chaloupecký a generace roku 1914. Otazníky české a slovenské historiografie v ére první republiky [Václav Chaloupecký and the 1914 generation. Issues of Czech and Slovak historiography in the era of the First Republic] (2018). Currently works on a project Evolutionism, Nationalism and Racism in the Czech and Slovak Science (1882-1948). E-mail: duchacekmilan@gmail.com 